\title{
BARRIERS TO KNOWLEDGE SHARING IN GLOBAL TEAMS - THEORETICAL PERSPECTIVE
}

\begin{abstract}
Organizing work in teams has become the modus operandi in multinational organizations and team-based structures are becoming a regular occurrence in every day operation of the organization. The purpose of this study is to run an extensive literature review of knowledge sharing barriers in global teams. It is assumed that global teams are able to integrate specialized and globally dispersed capabilities, to understand local needs and demands and leverage cultural diversity. These multi-cultural teams also face a host of problems, and to better understand the challenges and benefits of team work for global organizations, it is vital to learn what are the potential barriers in knowledge sharing.

This paper is one of the series concerning knowledge sharing barriers. Companies increasingly rely on global teams to foster growth and innovation, yet too often these teams are assembled without a clear process to ensure success. Global teams represent a high stake commitment, so it is imperative that these teams have a proven framework to promote optimal functioning. Firms need to pay attention to potential barriers to knowledge sharing, in order for global teams to succeed. The relevance of the barriers to knowledge sharing has been identified and they are as such: absorptive capacity, relationship between members of different teams, time, common framework, the excessive value attributed to experts, lack of recognition, distance, time zone and cultural differences.
\end{abstract}

Keywords: knowledge sharing, global team, barriers to knowledge sharing

\section{INTRODUCTION}

Today organizations are faced with uncertainty and fast-changing environments, and work tasks are becoming increasingly complex. Moreover companies in response to customers scattered in different countries open their subsidies in different parts of the world. Employees will have to communicate with each other. As a natural response, organizations have adopted team-based work structures to respond to these challenges ${ }^{2}$.

Because global teams are inherently diverse, differences and similarities should be acknowledged and harnessed as a source of innovation and new ideas. Global virtual teams are becoming the "new normal occurrence" as businesses expand across borders and as skill shortages force companies to tap into broader talent pools. Made possible by technology advances, the global virtual team offers many advantages, including ${ }^{3}$ :

- obtaining an international perspective on business challenges and solutions;

- achieving economies of scale;

\footnotetext{
${ }^{1}$ Celina Sołek-Borowska, PhD, Institute of Management, Department of Enterprise Management, The Warsaw School of Economics , Niepodległości 162, 02-554 Warsaw, mail: csolek@ sgh.waw.pl

${ }^{2}$ D. V. Day, P. Gronn, and E. Salas, E. (2006), "Leadership in team-based organizations: on the threshold of a new era", Leadership Quarterly, Vol. 17 No. 3, pp. 211-216. F. P. Morgeson D. S. DeRue, and E. P. Karam, (2010a), "Leadership in teams: a functional approach to understanding leadership structures and processes", Journal of Management, Vol. 36, pp. 5-39.

${ }^{3}$ M. Derven, Four drivers to enhance global virtual teams, Vol. 48, No. 1, 2016, pp. 1-8.
} 
- leveraging complementary work cycles that allow $24 / 7$ productivity;

- harnessing best talent, wherever it is located;

- accelerating innovation and product launches;

- enhancing local knowledge and presence.

Companies increasingly rely on global virtual teams to foster growth and innovation, yet too often these teams are assembled without a clear process to ensure success. Global virtual teams represent a high stakes commitment, so it is imperative that these teams have a proven framework to promote optimal functioning.

The aim of this paper is to analyze the barriers to knowledge sharing in global teams ${ }^{4}$. This paper is one of the series concerning knowledge sharing barriers. The research has been undertaken which investigates global teams located in India, UK, Czech Republic and Poland. This paper undertakes an extensive literature review. Therefore the empirical results will be presented in another paper of this series.

The remainder of the paper will first deal with a literature review of knowledge sharing in global teams followed by analyzing barriers in knowledge sharing in global teams.

\section{KNOWLEDGE SHARING WITHIN THE CONTEXT OF TEAM WORK}

Teams are likely to become the primary vehicle through which internal and external knowledge is shared in a company. Given the distributed nature of team work communication and knowledge sharing across distance is also one of their biggest challenges. When teams become regular occurrence in the organization, knowledge sharing between and across teams and their various stakeholders becomes particularly important. Teams will need to:

- focus on their internal task,

- make sure they maintain relationships and interactions with their various stakeholders, whether company-internal or company-external; and

- become more outward-looking.

For the purpose of this paper, global teams are defined as those with professionals located in different countries with different cultures ${ }^{5}$.

To enable knowledge sharing in organizations, members must have access to an arena in which to engage in interpersonal dialogue to share their experiences and knowledge with one another. Work team interactions provide a context in which individuals can engage in such dialogue ${ }^{6}$, as they involve a group of individuals embedded in a larger social system who work interdependently to perform tasks ${ }^{7}$. By highlighting the social interdependence of team members, this definition accounts for the social-constructivist nature of knowledge construction and individual members' contributions toward a shared understanding ${ }^{8}$.

\footnotetext{
${ }^{4}$ For the purpose of this paper the term global virtual team is used interchangeably with the term global team

${ }^{5}$ E.F McDonough, K. B. Kahn and G. Barczak, G. (2001), "An investigation of the use of global, virtual, and collocated new product development teams", The Journal of Product Innovation Management, Vol. 18 No. 2, pp. 110-120.

${ }^{6}$ T. E. J. Engström (2003), "Sharing knowledge through mentoring", Performance Improvement, Vol.42, pp.36-42.

${ }^{7}$ R. A. Guzzo and M. W. Dickson (1996), "Teams in organizations: research on performance and effectiveness", Annual Review of Psychology, Vol. 47 No. 1, pp. 307-338

${ }^{8}$ H. H. Tillema (2006), "Authenticity in knowledge-productive learning: what drives knowledge constructionincollaborativeinquiry?”,HumanResourceDevelopmentInternational,Vol.9 No.2, pp.173-190
} 
It is assumed that global teams are able to integrate specialized and globally dispersed capabilities, to understand local needs and demands and leverage cultural diversity. These multi-cultural teams also face a host of problems, and to better understand the challenges and benefits of team work for global organizations, it is vital to learn what are the potential barriers in knowledge sharing.

Teams have an important role in knowledge sharing9. In the context of team work, previous studies provide evidence that knowledge sharing in teams leads to superior team performance in different work environments such as research and development ${ }^{10}$, new product development ${ }^{11}$ and software development ${ }^{12}$. Knowledge sharing among an organization's team members is critical for competitive advantage ${ }^{13}$. The literature suggests that the sharing of knowledge in team work settings succeed only if team members actively engage in knowledge sharing and by the efficient management of knowledge for the use by new teams with new projects ${ }^{14}$.

Scholars view knowledge sharing as an organizational innovation, which leads to the dissemination of innovative ideas that has the potential to improve work processes and to develop new business opportunities ${ }^{15}$.

Knowledge sharing is argued to lead to better performance due to improved decision making and better coordination ${ }^{16}$. In practice, however, knowledge sharing has proven challenging ${ }^{17}$. And if knowledge is not shared, the cognitive resources available within a

${ }^{9}$ M. C. Becker, M.C. (2003), "What is the role of teams in knowledge management? Some indications from practice", International Journal of Information Technology and Management, Vol. 2 Nos 1/2, pp. 50-58.

${ }^{10}$ H. Berends, H. van der Bij, K. Debackere and M. Weggeman (2006), "Knowledge sharing mechanisms in industrial research", R\&D Management, Vol. 36 No. 1, pp. 85-95.

${ }^{11}$ P. Lee, N. Gillespie, L. Mann and A. Wearing (2010), "Leadership and trust: their effect on knowledge sharing and team performance", Management Learning, Vol. 41 No. 4, pp. 473-91.

${ }^{12}$ S. Faraj, and L. Sproull (2000), "Coordinating expertise in software development teams", Management Science, Vol. 46 No. 12, pp. 1554-68.

${ }^{13}$ R. M. Grant (1996), "Toward a knowledge-based theory of the firm”, Strategic Management Journal,Vol.17, No. S2, pp.109-122; L. A. Halawi, R. V. McCarthy and J. E. Aronson (2006), "Knowledge management and the competitive strategy of the firm", The Learning Organization, Vol. 13 No. 4, pp. 384-397; J. D. Pemberton and G. H. Stonehouse (2000), "Organisational learning and knowledge assets - an essential partnership", The Learning Organization, Vol. 7 No. 4, pp. 184-194.

${ }^{14}$ Ibidem

15 C.P. Lin, (2008) "Clarifying the relationship between organizational citizenship behaviors, gender, and knowledge sharing in workplace organizations in Taiwan”, Journal of Business Psychology, Vol. 22 No. 3, pp. 241-50. Lin, H-F. (2006), "Impact of organizational support on organizational intention to facilitate knowledge sharing", Knowledge Management Research \& Practice, Vol. 4, pp. 26-35; I. Nonaka and H. Takeuchi (1995), The Knowledge-creating Company: How Japanese Companies create the dynamics of innovation, Oxford University Press, New York; J. Yi (2009), "A measure of knowledge sharing behavior: scale development and validation”, Knowledge Management Research \& Practice, Vol. 7, pp. 65-81.

${ }^{16}$ C. Zarraga, and J. Bonache, J. (2003), “Assessing the team environment for knowledge sharing: an empirical analysis”, International Journal of Human Resource Management, Vol. 14 No. 7, pp. 1227-45.

${ }^{17}$ G. Szulanski (1996), "Exploring internal stickiness: impediments to the transfer of best practice within the firm", Strategic Management Journal, Vol. 17, pp. 27-44; L. Argote, P. Ingram, and J. M. Levine (2000), "Knowledge transfer in organizations: learning from the experience of others", Organizational Behavior \& Human Decision Processes, Vol. 82 No. 1, pp. 1-9. 
group remain underutilized ${ }^{18}$. This is particularly challenging in global teams where cultural and linguistic differences create barriers to communication and understanding. ${ }^{19}$

\section{KNOWLEDGE SHARING BARRIERS}

The use of global teams by firms has been boosted by the developments in technology that facilitate communication between team members located in different offices around the world, and it has quickly become a preferred option in high-tech firms ${ }^{20}$. The author thinks that it does not only apply to high-tech companies. Nowadays it is almost impossible to imagine the operation of the company who does not use new communication technologies regardless the size or the branch it operates in. Developments in communication technology have led to the need to analyze the routines of work teams, in an attempt to understand what types of resources are necessary for work teams to be effective and collaborative, whether they are local or geographically distributed ${ }^{21}$. It is worth to remember that barriers to knowledge sharing may also occur in co-located teams.

Absportive capacity is a barrier to knowledge sharing ${ }^{22}$. It is defined as a firm's ability to "identify, assimilate, and exploit knowledge from the environment" ${ }^{23}$. AC is also regarded as a dynamic capability, i.e. a capability that can be used to configure, develop, and deploy the resources of the firm in order to achieve competitive advantages.

The relationship between employees from the organization especially between members of different teams turns out to be another barrier to knowledge transfer ${ }^{24}$. Team members may not know personally and therefore they may have certain imagination of the person or even prejudices based on the style of writing an email, belonging to certain nation. Ignorance is due to the fact that those that have knowledge are not be visible, and those who need the knowledge do not know those who have $i^{25}$, which is classified as a

\footnotetext{
${ }^{18}$ L. Argote, (1999), Organizational Learning: Creating, Retaining, and Transferring Knowledge, Kluwer Academic, Boston, MA;

${ }^{19}$ D. C. Hambrick, S. C. Davison, S. A. Snell, and C. C. Snow (1998), "When groups consist of multiple nationalities", Organization Studies, Vol. 19 No. 2, pp. 181-206; M. A. Von Glinow, D. L. Shapiro, and J. M. Brett, J.M. (2004), "Can we talk, and should we? Managing emotional conflict in multicultural teams", Academy of Management Review, Vol. 29 No. 4, pp. 578-93.

${ }^{20}$ M. Monalisa, T. Daim, F. Miriani, P. Dash, R. Khamis and V. Bhusari (2008), "Managing global design teams", Research-Technology Management, Vol. 51 No. 4, pp. 48-59.

${ }^{21}$ E. W. Coakes, J. M. Coakes, and D. Rosenberg, D. (2008), "Co-operative work practices and knowledge sharing issues: a comparison of viewpoints”, International Journal of Information Management, Vol. 28 No. 1, pp. $12-25$.

${ }^{22}$ R. H. Assudani (2009), "Dispersed knowledge work - implications for knowledge intensive firms", Journal of Knowledge Management, Vol. 13 No. 8, pp. 521-532; A. Riege (2005), "Three-dozen knowledge sharing barriers managers must consider", Journal of Knowledge Management, Vol. 9 No. 3, pp. 18-35; M. Kyobe (2010), "A knowledge management approach to resolving the crises in the information systems discipline", Journal of Systems and Information Technology, Vol. 12 No. 2, pp. 161-173.

${ }^{23}$ W. M. Cohen and D. A. Levinthal (1990), "Absorptive capacity :a new perspective on learning and innovation”, Administrative Science Quarterly, Vol. 35 No. 1, pp. 128-152.

${ }^{24}$ A. Riege (2005), "Three-dozen knowledge sharing barriers managers must consider", Journal of Knowledge Management, Vol. 9 No. 3, pp. 18-35.

${ }^{25}$ C. O'Dell and C. J. Grayson (1998), "If only we knew what we know: identification and transfer of internal best practices", California Management Review, Vol. 40 No. 3, pp. 154-174.
} 
relationship barrier. It also known that the person we like we are more willing to share the knowledge we have.

Time is identified as a barrier ${ }^{26}$. Employees, generally are overloaded with work, have difficulty finding the time to share knowledge with their colleagues. It is much easier to share the knowledge, best practices whilst being in the same office. Time is a scare resource, there are always things that need to be done.

Common framework - geographically dispersed team members may not have a common framework, which may hinder collaboration ${ }^{27}$. It is being understood as the routines, ways how knowledge is shared including formal and informal ways. The existence of a framework that represents the effective knowledge dissemination is important for global team.

Organizational structure plays a significant role in the effective dissemination of knowledge. Boundryless organization seems to be the best solution in the process of knowledge sharing. Firms consisting of silo-type structures, with people divided into offices, locations and divisions will certainly experience difficulty in transferring knowledge between the teams. Visible barriers between departments may hinder effective collaboration. Each department may focus on achieving their own objectives forgetting about the company goal. This is due to the fact that team members will tend to focus solely on achieving their goals and not concern themselves with the goals of the organization as a whole. According to Wastell ${ }^{28}$ and Karlsen et $\mathrm{al}^{29}$. This is the responsibility of managers to build a knowledge sharing culture. Such manager should be self-aware, curious and committed to building a team culture of mutual respect, and creates an environment in which new ideas are encouraged and explored. To be fully effective, global team managers need to be sensitive to cultural backgrounds and how such biases can influence the level of participation from team members.

The excessive value attributed to experts also interferes with effective knowledge transfer. In many cases employees believe that their future depends on their development as an expert, and so struggle to attain or maintain hegemony over knowledge instead of seeking to share $i^{30}$. Experts or consultants are perceived as those with capabilities and experience which may diminish other employees. Lack of recognition also interferes with the proper interaction between team members. The absence of recognition of employees who spend time learning, sharing and helping teams or members from outside their own scope eventually discourages them from continuing to do $\mathrm{so}^{31}$. The firms' strategic deci-

\footnotetext{
${ }^{26}$ A. Riege (2005), "Three-dozen knowledge sharing barriers managers must consider", Journal of Knowledge Management, Vol. 9 No. 3, pp. 18-35.

${ }^{27}$ R. H. Assudani (2009), "Dispersed knowledge work - implications for knowledge intensive firms", Journal of Knowledge Management, Vol. 13 No. 8, pp. 521-532.

${ }^{28}$ D G. Wastell (2001), "Barriers to effective knowledge management: action research meets grounded theory", Journal of Systems and Information Technology, Vol. 5 No. 1, pp. 21-36.

${ }^{29}$ J. T. Karlsen, L. Hagman and T. Pedersen (2011), "Intra-project transfer of knowledge in information systems development firms", Journal of Systems and Information Technology, Vol. 3 No. 1, pp. 66-80.

${ }^{30}$ M. Alavi and D. E. Leidner (2001), "Review: knowledge management and knowledge management systems: conceptual foundations and research issues", MIS Quarterly,Vol.25 No. 1, pp. 107-137; N. Levina and E. Vaast (2008), "Innovation or doing as told? Status differences and overlapping boundaries in offshore collaboration", MIS Quarterly, Vol. 32 No. 2, pp. 307-332.

${ }^{31}$ C. O'Dell and C. J. Grayson (1998), "If only we knew what we know: identification and transfer of internal best practices", California Management Review, Vol. 40 No. 3, pp. 154-174; L. J. Yao, T. H. Y. Kam and S.
} 
sion to use global teams leads to some specific barriers such as distance, time zone and cultural differences.

Distance is cited by some authors as a barrier to knowledge dissemination as it reduces or totally excludes face-to-face interaction, and makes shared identity difficult to achieve $^{32}$. Nothing will replace face to face contact even though nowadays companies have got a large It tools to have contact online with team members.

The fact that teams work in different time zones teams may be a barrier for knowledge sharing. It requires a greater need for explicit knowledge so that there is exchange of knowledge. According to the authors, in firms that have geographically distributed teams they use tools such as intranets, groupware and knowledge base. Cultural differences are pointed out as one of the reasons for the failure in offshore software development projects ${ }^{33}$. Different countries have different ways of working that sometimes hinder interaction and cause conflicts between teams ${ }^{34}$. Cultural differences are identified as one the greatest impediments to effective knowledge sharing ${ }^{35}$. The reserved culture which is particular to some countries, such as China, could represent a barrier to knowledge sharing, as it could be interpreted as "showing off" 36.

The use of global teams by firms has benefits; on the other hand, knowledge sharing becomes more complex. Understanding the barriers to knowledge sharing in global teams may positively influence the achievement of offshore benefits.

\section{CONCLUSION}

New ways of working are required in today's interconnected world, which reflects the changing realities of globalization, where collaboration and speed are paramount. The widespread adoption of team structures to organize and complete organizational tasks is one of the major changes in work and organizations that has occurred during the last 50 years. In 1959, when individual work characterized organizations, Peter Drucker predicted the movement toward team structures in future organizations along with the emergence of the "knowledge-worker," a term he coined at the time. This paper has contributed to the growing body of literature on knowledge sharing barriers.

Firms need to pay attention to potential barriers to knowledge sharing, in order for global teams to succeed. The relevance of the barriers to knowledge sharing has been identified and they are a such: absorptive capacity, relationship between members of dif-

H. Chan (2007), "Knowledge sharing in Asian public administration sector: the case of Hong Kong", Journal of Enterprise Information Management, Vol. 20 No. 1, pp. 51-69.

${ }^{32}$ N. Levina and E. Vaast (2005), "The emergence of boundary spanning competence practice: implications for implementation and use of information systems", MIS Quarterly, Vol. 29 No. 2, pp. 335-363; J. Kotlarsky, P. C. vanFenema, and L. Willcocks (2008), "Developing a knowledge-based perspective on coordination: the case of global software projects", Information \& Management, Vol. 45 No. 2, pp. 96-108.

${ }^{33}$ M.Alavi, and Leidner, D.E. (2001), "Review: knowledge management and knowledge management systems: conceptual foundations and research issues", MIS Quarterly,Vol.25 No. 1, pp. 107-137.

${ }^{34}$ S. Krishna, S. Sahay and G. Walsham (2004), "Managing cross-cultural issues in global software outsourcing", Communications of the ACM, Vol. 47 No. 4, pp. 62-66.

${ }^{35}$ M. Alavi, and D. E. Leidner, (2001), "Review: knowledge management and knowledge management systems: conceptual foundations and research issues”, MIS Quarterly,Vol.25 No. 1, pp. 107-137.

${ }^{36}$ L. J. Yao, T.H.Y. Kam and S.H. Chan (2007), "Knowledge sharing in Asian public administration sector: the case of Hong Kong”, Journal of Enterprise Information Management, Vol. 20 No. 1, pp. 51-69. 
ferent teams, time, common framework, the excessive value attributed to experts, lack of recognition, distance, time zone and cultural differences.

This research offers a thorough analysis of potential barriers in knowledge sharing. The present research should encourage researchers to continue to examine further barriers and enablers in knowledge sharing.

\section{LITERATURE}

[1] Alavi, M. and Leidner, D.E. (2001), "Review: knowledge management and knowledge management systems: conceptual foundations and research issues", MIS Quarterly,Vol.25 No. 1, pp. 107-137.

[2] Argote, L. (1999), Organizational Learning: Creating, Retaining, and Transferring Knowledge, Kluwer Academic, Boston, MA.

[3] Argote, L., Ingram, P. and Levine, J.M. (2000), "Knowledge transfer in organizations: learning from the experience of others", Organizational Behavior \& Human Decision Processes, Vol. 82 No. 1, pp. 1-9.

[4] Assudani, R.H. (2009), "Dispersed knowledge work - implications for knowledge intensive firms", Journal of Knowledge Management, Vol. 13 No. 8, pp. 521-532.

[5] Becker, M.C. (2003), "What is the role of teams in knowledge management? Some indications from practice", International Journal of Information Technology and Management, Vol. 2 Nos $1 / 2$, pp. 50-58.

[6] Berends, H., van der Bij, H., Debackere, K. and Weggeman, M. (2006), "Knowledge sharing mechanisms in industrial research", R\&D Management, Vol. 36 No. 1, pp. 85-95.

[7] Cabrera, E.F. and Cabrera, A. (2005), "Fostering knowledge sharing through people management practices", International Journal of Human Resource Management, Vol. 16 No. 5, pp. 720-36.

[8] Coakes, E.W., Coakes, J.M. and Rosenberg, D. (2008), "Co-operative work practices and knowledge sharing issues: a comparison of viewpoints", International Journal of Information Management, Vol. 28 No. 1, pp. 12-25.

[9] Cohen, W. M. and Levinthal D.A.(1990), "Absorptive capacity :a new perspective on learning and innovation", Administrative Science Quarterly, Vol. 35 No. 1, pp. 128-152.

[10] Day, D.V., Gronn, P. and Salas, E. (2006), "Leadership in team-based organizations: on the threshold of a new era", Leadership Quarterly, Vol. 17 No. 3, pp. 211-216.

[11] Derven, M., Four drivers to enhance global virtaul teams, Vol. 48, No. 1, 2016, pp. 1-8.

[12] Engström, T.E.J. (2003), "Sharing knowledge through mentoring", Performance Improvement, Vol.42,pp.36-42.

[13] Faraj, S. and Sproull, L. (2000), "Coordinating expertise in software development teams", Management Science, Vol. 46 No. 12, pp. 1554-68.

[14] Grant, R.M. (1996), "Toward a knowledge-based theory of the firm", Strategic Management Journal,Vol.17No.S2,pp.109-122.

[15] Guzzo,R.A.andDickson,M.W.(1996),“Teamsinorganizations:recentresearchonperformance and effectiveness", Annual Review of Psychology, Vol. 47 No. 1, pp. 307-338

[16] Halawi, L.A., McCarthy, R.V. and Aronson, J.E. (2006), "Knowledge management and the competitive strategy of the firm", The Learning Organization, Vol. 13 No. 4, pp. 384-397.

[17] Hambrick, D.C., Davison, S.C., Snell, S.A. and Snow, C.C. (1998), "When groups consist of multiple nationalities", Organization Studies, Vol. 19 No. 2, pp. 181-206.

[18] Karlsen, J.T., Hagman, L. and Pedersen, T. (2011), "Intra-project transfer of knowledge in information systems development firms", Journal of Systems and Information Technology, Vol. 3 No. 1, pp. 66-80.

[19] Kotlarsky,J.,vanFenema,P.C.andWillcocks,L.(2008), “Developingaknowledgebasedperspective on coordination: the case of global software projects", Information \& Management, Vol. 45 No. 2, pp. 96-108. 
[20] Krishna, S., Sahay, S. and Walsham, G. (2004), "Managing cross-cultural issues in global software outsourcing", Communications of the ACM, Vol. 47 No. 4, pp. 62-66.

[21] Kyobe, M. (2010), "A knowledge management approach to resolving the crises in the information systems discipline", Journal of Systems and Information Technology, Vol. 12 No. 2, pp. 161-173.

[22] Lee, P., Gillespie, N., Mann, L. and Wearing, A. (2010), "Leadership and trust: their effect on knowledge sharing and team performance", Management Learning, Vol. 41 No. 4, pp. 473-91.

[23] Levina, N. and Vaast, E. (2005), "The emergence of boundary spanning competence practice: implications for implementation and use of information systems", MIS Quarterly, Vol. 29 No. 2, pp. 335-363.

[24] Levina, N. and Vaast, E. (2008), "Innovation or doing as told? Status differences and overlapping boundaries in offshore collaboration", MIS Quarterly, Vol. 32 No. 2, pp. 307-332.

[25] Lin, C-P. (2008), "Clarifying the relationship between organizational citizenship behaviors, gender, and knowledge sharing in workplace organizations in Taiwan", Journal of Business Psychology, Vol. 22 No. 3, pp. 241-50. Lin, H-F. (2006), "Impact of organizational support on organizational intention to facilitate knowledge sharing", Knowledge Management Research \& Practice, Vol. 4, pp. 26-35.

[26] McDonough, E.F. III, Kahn, K.B. and Barczak, G. (2001), "An investigation of the use of global, virtual, and collocated new product development teams", The Journal of Product Innovation Management, Vol. 18 No. 2, pp. 110-120.

[27] Monalisa, M., Daim, T., Miriani, F., Dash, P., Khamis, R. and Bhusari, V. (2008), "Managing global design teams", Research-Technology Management, Vol. 51 No. 4, pp. 48-59.

[28] Morgeson, F.P., DeRue, D.S. and Karam, E.P. (2010a), "Leadership in teams: a functional approach to understanding leadership structures and processes", Journal of Management, Vol. 36 , pp. 5-39.

[29] Nonaka, I. and Takeuchi, H. (1995), The Knowledge-creating Company: How Japanese Companies create the dynamics of innovation, Oxford University Press, New York.

[30] O’Dell, C. and Grayson, C.J. (1998), "If only we knew what we know: identification and transfer of internal best practices", California Management Review, Vol. 40 No. 3, pp. 154174.

[31] Pemberton, J.D. and Stonehouse, G. H. (2000), “Organisational learning and knowledge assets - an essential partnership", The Learning Organization, Vol. 7 No. 4, pp. 184-194.

[32] Riege, A. (2005), "Three-dozen knowledge sharing barriers managers must consider", Journal of Knowledge Management, Vol. 9 No. 3, pp. 18-35.

[33] Szulanski, G. (1996), "Exploring internal stickiness: impediments to the transfer of best practice within the firm", Strategic Management Journal, Vol. 17, pp. 27-44.

[34] Tillema, H.H. (2006), "Authenticity in knowledge-productive learning: what drives knowledge constructionincollaborativeinquiry?",HumanResourceDevelopmentInternational,Vol.9 No.2,pp.173-190

[35] Von Glinow, M.A., Shapiro, D.L. and Brett, J.M. (2004), "Can we talk, and should we? Managing emotional conflict in multicultural teams", Academy of Management Review, Vol. 29 No. 4, pp. 578-93.

[36] Yao, L.J., Kam, T.H.Y. and Chan, S.H. (2007), "Knowledge sharing in Asian public administration sector: the case of Hong Kong”, Journal of Enterprise Information Management, Vol. 20 No. 1, pp. 51-69.

[37] Yi, J. (2009), "A measure of knowledge sharing behavior: scale development and validation", Knowledge Management Research \& Practice, Vol. 7, pp. 65-81.

[38] Zarraga, C. and Bonache, J. (2003), "Assessing the team environment for knowledge sharing: an empirical analysis", International Journal of Human Resource Management, Vol. 14 No. 7 , pp. 1227-45. 


\section{BARIERY DZIELENIA SIE WIEDZĄ W ZESPOŁACH GLOBALNYCH}

Organizowanie pracy w zespołach stało się modus operandi w firmach międzynarodowych, dlatego zespoły pracownicze stają się zjawiskiem powszechnie występującym w każdym dziale przedsiębiorstwa. Zakłada się, że globalne zespoły są w stanie zintegrować specjalistyczne umiejętności rozproszone na całym świecie w celu zrozumienia potrzeb i wymagań lokalnych oraz wpływu różnorodności kulturowej. Te zespoły wielokulturowe również stają w obliczu wielu problemów i aby lepiej zrozumieć wyzwania i korzyści pracy zespołowej dla globalnych organizacji ważne jest aby dowiedzieć się, jakie są potencjalne bariery w dzieleniu się wiedzą. Celem niniejszej pracy jest zaprezentowanie przeglądu literatury przedmiotu w zakresie barier dzielenia się wiedzą w globalnych zespołach. Niniejszy artykuł jest jednym z serii prac poświęconych dzieleniu się wiedzą w zespołach globalnych. Firmy coraz częściej opierają się na globalnych zespołach, aby wspierać w ten sposób swój rozwój oraz innowacyjność, niestety często też zespoły te są powoływane bez wyraźnego ukierunkowania na cel. Globalne zespoły stanowią najwyższy poziom zaangażowania pracowników, więc konieczne jest, aby te zespoły posiadały sprawdzony sposób funkcjonowania. Firmy muszą zwracać uwagę na potencjalne bariery dla wymiany wiedzy, w celu osiągnięcia sukcesu przez nie. Znaczenie barier dla wymiany wiedzy zostało zidentyfikowane i są one następujące: zdolność do absorpcji, relacje między członkami różnych zespołów, czas, wspólne ramy, nadmierna wartość przypisana ekspertom, brak uznania, dystans, strefa czasowa oraz różnice kulturowe.

Słowa kluczowe: dzielenie się wiedzą, globalny zespół, bariery w dzieleniu się wiedzą

\section{DOI: 10.7862/rz.2015.mmr.61}

Tekst złożono w redakcji: styczeń 2016

Przyjęto do druku: styczeń 2016 